九州大学学術情報リポジトリ

Kyushu University Institutional Repository

\title{
Clubroot Resistance in Brussicoruphanus
}

Xing, Guo Ming

University Farm, Faculty of Agriculture, Kyushu University

Long, Ming Hua

University Farm, Faculty of Agriculture, Kyushu University

Tanaka, Shuhe i

Laboratory of Plant Pathology, Faculty of Agriculture, Yamaguchi University

Fujieda, Kunimitsu

University Farm, Faculty of Agriculture, Kyushu University

https://doi.org/10.5109/23928

出版情報：九州大学大学院農学研究院紀要. 33 (3/4)，pp. 189-194，1989-03. Kyushu University バージョン：

権利関係 : 


\title{
Clubroot Resistance in Brussicoruphanus
}

\author{
Guo $M$ ing Xing*, M ing $H$ ua Long, Shuhei Tanaka** \\ and K unimitsu Fujieda
}

University Farm, Faculty of Agriculture, Kyushu University 46-10, Kasuya-machi, Fukuoka 811-23, Japan.

(Received August 31, 1988)

\begin{abstract}
Clubroot-resistance in Brassicoraphanus $(2 \mathrm{n}=36$; ccrr genome), which originated from the progeny of Brassica oleracea var. capitata cv. Miikechusei $\times$ Raphanus sativus var. longipin natus (the cultivar is unknown), was tested using Williams' races 2 and 4 in comparison with some cruciferous crops with an insertion-inoculation method. Three strains of Brassicoraphanus were not infected with the two physiological races suggesting this intergeneric plant has a stable and strong resistant gene to clubroot disease. Neither hybrids between Bmssicoraphunus and high to moderate resistant cultivars of Japanese radish or cabbage nor hybrids between Brassicoraphanus and susceptible cultivars of Chinese cabbage or turnip were infected with the two races. It is concluded from these results that clubroot resistance in Bmssicoraphunus is controlled by a dominant gene, and that Brassicoraphanus is useful for breeding clubroot resistant cruciferous plants.
\end{abstract}

\section{INTRODUCTION}

Clubroot is a soil borne disease of cruciferous plants caused by parasitism of Plasmodiophora brassicae Woronin. The Mediterranean coast has been supposed to be the center of origin of the disease. At present, the disease has expanded throughout the world and has been considered one of the most damaging disease of cruciferous crops (Watson, 1969).

P. brassicae parasitizes only in the roots of cruciferous plants. The infected root enlarges abnormally like a club and becomes fragile. When the main root is infected with the pathogen, the plant wilts and defoliates because of the difficulty in water absorption in the root, and in the worst case it results in death. Since P. brassicae lives in soil for several years and effective and safe fungicides have not been improved, cruciferous plants with the disease resistance had been screened by some workers (Walker, 1936, 1939 ; Ashizawa et al., 1978, 1980). Based on these criteria, breeding of clubroot disease-resistant cultivars of cruciferous plants had been conducted (Yoshikawa et al., 1981 ; Yoshikawa, 1983). According to Yoshikawa et al. (1988), several clubroot-resistant cultivars of Chinese cabbage have been, to some extent, infected with clubroot in some regions. Hence, the stability of clubroot disease resistance in the cultivars is suspected by them. Thus, further possible measures to estimate the disease resistance will be necessary in cruciferous crops including Chinese cabbage.

*Present address : Department of Horticulture, Shan Xi Agricultural University, Ta Gou, Shan Xi, China

** Laboratory of Plant Pathology, Faculty of Agriculture, Yamaguchi University 
Generally, Raphanus plants have high potentials of clubroot disease resistance (Ashizawa et al., 1980). Since it is expected that the intergeneric hybrid Brassicoraphanus (Fukushima, 1945) has the potentials of clubroot disease resistance, this is a very important plant for mediating genes to both genera Brassica and Raphanus through hybridization. The purpose of the present study was to estimate the clubroot resistance in Brassicoraphanus and demonstrate its usefulness for breeding the cruciferous plants resistant to clubroot disease.

\section{MATERIALS AND METHODS}

\section{Experiment 1. Estimation of clubroot resistance in Brassicoraphanus}

Three strains of Brassicoraphanus, which is symbolized as $K(2 \mathrm{n}=\mathbf{3 6}$; ccrr genome), and cole crops (Table 2) were used as plant materials. Two physiological races of Plasmodiophora brassicae Williams' race 2 and Hagikin were used, Williams' race 2 was provided by the Vegetable and Ornamental Crops Research Station.

The spores of the two races were suspended to count as follows. Fifty grams of clubbed roots stored at $-20^{\circ} \mathrm{C}$ were homogenized in $400 \mathrm{ml}$ water and the homogenate was filtered through the eight layers of cheesecloth. Then, the filtrate was centrifuged at $2,000 \mathrm{~g}$ for 5 minutes. The supernatant was discarded and the remaining pellet containing the spores was suspended in water. This centrifugation and suspension steps were repeated five times to remove the impurities. After the final step, the spores were counted to calculate a spore load under a microscope with a hemocytometer.

An inoculation method described by Yoshikawa et al. (1981) was applied with some modifications as follows. A mixture of sphagnum moss, perlite and clay powder (1: $3: 1$ by weight) was made and adjusted to $\mathrm{pH} 5.8$ with $\mathrm{CaCO}_{3}$. The spores were injected into the mixture of the soils in which a spore load was $5 \times 10^{5}$ per gram of the dry matter. Cylindrical medium blocks measuring $4 \mathrm{~cm} \times 3 \mathrm{~cm}$ were made of the mixture and inserted into plastic pots $(11 \mathrm{~cm}$ in diameter $)$ stuffed with vermiculite. Seeds of Brassicoraphanus and cole crops were sown on the blocks on July 2, 1986 and thinly covered up with a mixture made of perlite and vermiculite (1:1 by weight). The young plants were fertilized with a $0.1 \%$ solution of a compound fertilizer, OK-F-1 (Otsuka Chemical Company). The extent of clubbing formed in the roots of the plants was examined seven weeks after sowing.

The degree of infection was divided into five classes, A to E (Table 1) according to Yoshikawa et al. (1981) with some modifications.

Table 1. The degree of clubroot disease in the roots of $K$ and cole crops.

\begin{tabular}{clc}
\hline Class & Degree of clubing in roots & \% of roots infected \\
\hline B. & nonclubbed & 0 \\
C & slightly clubbed & $1-10$ \\
& moderately clubbed & $11-30$ \\
D & severely clubbed & $31-60$ \\
E & very severely clubbed" & $61-100$ \\
\hline
\end{tabular}

a: A few and small clubs formed in roots.

$\mathrm{b}$ : Each club is not jointed in a root.

c: Each club is jointed even in a fibrous root. 


\section{Experiment 2. Estimation of clubroot resistance in the hybrids between Brassicoraphanus and cole crops}

Clubroot resistance in 4 hybrids obtained by crossing K-11 with Chinese cabbage cv. Kyoto No. 3, turnip cv. Nagasakiaka, cabbage cv. Miikechusei and radish cv. Minowase was compared with that in their parents. Culture and inoculation methods, pathogens and evaluation of clubroot resistance were the same as those described in Experiment 1. The seeds were sown on July 22, 1987 and the degree of clubbing formed in the roots was examined 45 days after sowing.

\section{RESULTS AND DISCUSSION}

As shown in Table 2, all the plants of Chinese cabbage, Chinese mustard and

Table 2. Response of $K$ and cole crops to clubroot disease.

\begin{tabular}{|c|c|c|c|c|}
\hline $\begin{array}{l}\text { Strain and } \\
\text { cultivar }\end{array}$ & $\begin{array}{l}\text { Race of } \\
\text { clubroot* }\end{array}$ & $\begin{array}{l}\text { No. of } \\
\text { plants } \\
\text { examined }\end{array}$ & $\begin{array}{l}\text { Percentage } \\
\text { of infected } \\
\text { plants }\end{array}$ & $\begin{array}{l}\text { Disease } \\
\text { index ** }\end{array}$ \\
\hline \multicolumn{5}{|l|}{ Brassicoraphanus } \\
\hline \multirow[t]{2}{*}{$K-3$} & a & 24 & 0 & 0 \\
\hline & b & 19 & 0 & 0 \\
\hline \multirow[t]{2}{*}{ K-11 } & a & 24 & 0 & 0 \\
\hline & b & 21 & 0 & 0 \\
\hline \multirow[t]{2}{*}{$\mathrm{K}-13$} & a & 22 & 0 & 0 \\
\hline & $\mathrm{b}$ & 23 & 0 & 0 \\
\hline \multicolumn{5}{|l|}{ Chinese cabbage } \\
\hline \multirow{2}{*}{ Nozaki No. 2} & a & 22 & 100 & 100 \\
\hline & $\mathrm{b}$ & 24 & 100 & 90 \\
\hline \multirow[t]{2}{*}{ Kashin } & $\mathrm{a}$ & 23 & 100 & 76 \\
\hline & b & 23 & 100 & 83 \\
\hline \multicolumn{5}{|l|}{ Chinese mustard } \\
\hline \multirow[t]{2}{*}{ Komatsuna } & a & 24 & 100 & 90 \\
\hline & $\mathrm{b}$ & 25 & 100 & 95 \\
\hline \multirow[t]{2}{*}{ Green debut } & a & 23 & 100 & 100 \\
\hline & $\mathrm{b}$ & 25 & 100 & 100 \\
\hline \multicolumn{5}{|l|}{ Turnip } \\
\hline \multirow[t]{2}{*}{ Azumakanamachi } & $\mathbf{a}$ & 19 & 100 & 87 \\
\hline & b & 23 & 100 & 87 \\
\hline \multirow[t]{2}{*}{ Hakatasuwari } & $\mathrm{a}$ & 25 & 100 & 66 \\
\hline & $\mathrm{b}$ & 25 & 100 & 49 \\
\hline \multicolumn{5}{|l|}{ Cabbage } \\
\hline \multirow[t]{2}{*}{ Miikechusei } & a & 25 & 12 & 1 \\
\hline & $\mathrm{b}$ & 25 & 56 & 32 \\
\hline \multirow[t]{2}{*}{ Natsumine } & a & 25 & 52 & 5 \\
\hline & $\mathrm{b}$ & 24 & 88 & 45 \\
\hline \multicolumn{5}{|l|}{ Japanese radish } \\
\hline \multirow[t]{2}{*}{ Minowase } & a & 16 & 31 & 7 \\
\hline & $\mathrm{b}$ & 11 & 100 & 54 \\
\hline \multirow[t]{2}{*}{ Shijunichi } & a & 24 & 0 & 0 \\
\hline & $\mathrm{b}$ & 25 & 0 & 0 \\
\hline
\end{tabular}

* a : Williams' race $2 ; \mathrm{b}$ : Hagikin.

** Index $=\frac{0 \mathrm{~A}+10 \mathrm{~B}+30 \mathrm{C}+60 \mathrm{D}+100 \mathrm{E}}{\mathrm{A}+\mathrm{B}+\mathrm{C}+\mathrm{D}+\mathrm{E}}, \mathrm{A}$ to $\mathrm{E}$ : see Table 1 
turnip cultivars were infected very severely, whereas none of these strains of $K$ plants were infected with either of the two physiological races of $P$. bmssicae. In cabbage, disease indices of both cultivars were low to the Williams' race 2(a) but high to the Hagikin(b). The Japanese radish 'Shijunichi' was not infected with any of the two races, but 'Minowase' was. These results suggest that the crops of $K$ group are almost stable and strongly clubroot-resistant, that Japanese radish is resistant but not stable depending on the cultivars, and that others are not resistant.

Diversity of physiological race in P. brassicae is remarkable, and Williams' races 1, 2, 3, 4, 5, 8 and 9 have also been reported in Japan (Yoshikawa, 1983). However, screening of breeding materials and subsequent resistant breeding have been carried out to use a few special races according to the viewpoint that if plants are strongly resistant to one physiological race they are also strongly resistant to the other races (Nieuwhof and Wiering, 1963 ; Yoshikawa, 1983). A dominant gene, which governs clubroot resistance in European fodder turnip, has been transferred into Chinese cabbage (Yoshikawa, 1983), resulting several clubroot resistant cultivars which have now been growing over wide areas. Recently, these resistant cultivars have been infected with clubroot disease in several regions of Japan. Hence, more permanent stability of clubroot disease resistance in these cultivars is now required (Yoshikawa et al., 1988).

Pathogens used in this experiment were Williams' race 2 and Hagikin. The Hagikin belongs to Williams' race 4 (Tanaka et al., unpublished). Crops of $K$ group are not only strongly resistant to Williams' races 2 and 4 but are also strongly resistant to Williams' races 1 and 9 (Tanaka et al., personal communication). Therefore, it may be concluded that $K$ crops are stable and resistant to various races of $P$. bmssicae.

Results of Experiment 2 are shown in Table 3. In this experiment, the trend of the results was similar to that in Experiment 1 in Chinese cabbage, turnip, cabbage and Japanese radish cultivars. All plants of the cultivars of Chinese cabbage and turnip were very severely infected with the two races of P.brassicae. In cabbage, 'Toyomine No. 2' was severely infected with Hagikin whereas the degree of infection with Williams' race 2 ranged from A to E. A Japanese radish cultivar 'Minowase' was not infected with Williams' race 2. About a half of the plants of 'Minowase' was severely infected with Hagikin but the remaining plants were not infected. This clear segregation of clubroot disease-resistant plants in commercial varieties of cabbage and Japanese radish is especially noticeable, because when genes for resistance occur in existing commercial varieties, selection with these varieties will almost always provide the earliest and most satisfactory method of developing resistant strains (Allard, 1960).

Three strains of $K$ and four $F_{1}$ hybrids between $K$ and cole crops were not infected with the two physiological races. Considering that all hybrids between $K$ and susceptible cultivars of Chinese cabbage and turnip were resistant, it may be concluded that clubroot resistance in $K$ is governed by a dominant gene.

$K$ is an amphidiploid bred from the progency of Brassica oleracea var. capitata $c v$. Miikechusei $\mathbf{x}$ Raphanus sativus var. longipinnatus (the cultivar is unknown ;Fukushima, 1945). Because of the extinction of the parental lines, it is difficult to prove whether the clubroot-resistant gene of $K$ was a parental origin, mutual complement of its parental resistant genes or a mutation during the preservation and selection of the line. However, there are two evidences that $K$ may have inherited the resistance from 
Table 3. Response of $K$, cole crops and their hybrids to clubroot disease.

\begin{tabular}{|c|c|c|c|c|c|c|c|c|c|}
\hline \multirow{2}{*}{$\begin{array}{l}\text { Strain, cultivar } \\
\text { and hybrid }\end{array}$} & \multirow{2}{*}{$\begin{array}{c}\text { Race } \\
\text { of } \\
\text { clubroot }\end{array}$} & \multirow{2}{*}{$\begin{array}{l}\text { No. of } \\
\text { plants } \\
\text { * examined }\end{array}$} & \multicolumn{5}{|c|}{$\begin{array}{l}\text { No. of infected } \\
\text { plants in } 5 \text { classes } \\
\text { of infection }\end{array}$} & \multirow{2}{*}{$\begin{array}{c}\text { Percentage } \\
\text { of infected } \\
\text { plants }\end{array}$} & \multirow{2}{*}{$\begin{array}{l}\text { Disease } \\
\text { index** }\end{array}$} \\
\hline & & & A & B & $\mathrm{C}$ & $\mathrm{D}$ & $\mathrm{E}$ & & \\
\hline \multicolumn{10}{|l|}{ Chinese cabbage } \\
\hline \multirow[t]{2}{*}{ Kyoto No. 3} & a & 18 & 0 & 0 & 0 & 0 & 18 & 100 & 100 \\
\hline & $b$ & 24 & 0 & 0 & 0 & 0 & 24 & 100 & 100 \\
\hline \multicolumn{10}{|l|}{ Turnip } \\
\hline \multirow[t]{2}{*}{ Nagasakiaka } & a & 24 & 0 & 0 & 0 & 0 & 24 & 100 & 100 \\
\hline & $b$ & 20 & 0 & 0 & 0 & 0 & 20 & 100 & 100 \\
\hline \multicolumn{10}{|l|}{ Cabbage } \\
\hline \multirow[t]{2}{*}{ Toyomine No. 2} & a & 23 & 8 & 1 & 2 & 1 & 11 & 65 & 54 \\
\hline & b & 23 & 0 & 0 & 0 & 0 & 23 & 100 & 100 \\
\hline \multicolumn{10}{|l|}{ Japanese radish } \\
\hline \multirow[t]{2}{*}{ Minowase } & a & 26 & 26 & 0 & 0 & 0 & 0 & 0 & 0 \\
\hline & $\mathrm{b}$ & 19 & 10 & 0 & 0 & 0 & 9 & 47 & 47 \\
\hline \multicolumn{10}{|l|}{ Brassicoraphanus } \\
\hline \multirow{2}{*}{$K-3$} & a & 17 & 17 & 0 & 0 & 0 & 0 & 0 & 0 \\
\hline & $\mathrm{b}$ & 20 & 20 & 0 & 0 & 0 & 0 & 0 & 0 \\
\hline \multirow[t]{2}{*}{$\mathrm{K}-11$} & a & 24 & 24 & 0 & 0 & 0 & 0 & 0 & 0 \\
\hline & b & 22 & 22 & 0 & 0 & 0 & 0 & 0 & 0 \\
\hline \multirow[t]{2}{*}{$\mathrm{K}-13$} & a & 25 & 25 & 0 & 0 & 0 & 0 & 0 & 0 \\
\hline & b & 24 & 24 & 0 & 0 & 0 & 0 & 0 & 0 \\
\hline \multicolumn{10}{|l|}{$F_{1}$ hybrids } \\
\hline \multirow[t]{2}{*}{ K-11 x Kyoto No. 3} & a & 11 & 11 & 0 & 0 & 0 & 0 & 0 & 0 \\
\hline & b & 12 & 12 & 0 & 0 & 0 & 0 & 0 & 0 \\
\hline \multirow[t]{2}{*}{ K-11 x Nagasakiaka } & a & 4 & 4 & 0 & 0 & 0 & 0 & 0 & 0 \\
\hline & b & 3 & 3 & 0 & 0 & 0 & 0 & 0 & 0 \\
\hline \multirow[t]{2}{*}{ K-11 $\times$ Minowase } & $\mathrm{a}$ & 13 & 13 & 0 & 0 & 0 & 0 & 0 & 0 \\
\hline & $\mathrm{b}$ & 13 & 13 & 0 & 0 & 0 & 0 & 0 & 0 \\
\hline$K-11 \times$ Miikechusei & $\mathrm{b}$ & 2 & 2 & 0 & 0 & 0 & 0 & 0 & 0 \\
\hline
\end{tabular}

*See Table $2 ; * *$ See Tables 1 and 2 .

the pollen parent Japanese radish. One evidence is that clubroot resistant Raphanobrassica has been bred by using the combination of fodder kale and European fodder radish, and the latter is stably resistant to the various races of P.brassicae (McNaughton, 1973). Another is that many resistant cultivars existed among Japanese radish to Williams' race 2 (Ashizawa et al., 1980).

Forty years have passed since $\boldsymbol{K}$ was bred. Its seed fertility has been obtained through selections during this period. $\boldsymbol{K}$ is a self-fertilizing plant and the inbreeding depression has not occurred until now. Because of this breeding potential, $\boldsymbol{K}$ is considered to be a bridge plant for breeding clubroot resistant cultivars in cole vegetables. Although hybrids between $\boldsymbol{K}$ and radish were easily obtained in our experiment, it was difficult to obtain hybrids by crossing $\boldsymbol{K}$ with cabbage, Chinese cabbage and turnip because of seed abortion and cross incompatibility. Development of efficient breeding methods to overcome these problems is necessary for the establishment of breeding of clubroot resistant cole crop varieties. 


\section{REFERENCES}

Allard, R. W. 1960 Principles of plant breeding. John Wiley \& Sons, New York

Ashizawa, M., H. Yoshikawa, K. Hida, T. Kameno, I. Morita and K. Takatsuka 1978 Studies on the breeding of clubroot-resistance in cole crops. I. Screening of cole crops for clubroot-resistance. Bull. Veg. \& Omam. Crops Res. Sta., A4 : 1-25 (in Japanese with English summary)

Ashizawa, M., H. Yoshikawa and K. Hida 1980 Studies on the breeding of clubroot-resistance in cole crops. II. Screening of cole crops for clubroot-resistance. Bull. Veg. \& Omam. Crops Res. Sta., A7 :35-75 (in Japanese with English summary)

Fukushima, E. 1945 Cytogenetic studies on Brassica and Raphanus. I. Studies on the intergeneric $\mathrm{F}_{1}$ hybrids between Brassica and Raphanus. Jour. Dept. Agri. Kyushu Imp. Univ., 7 : 281-400

McNaughton, I. H. 1973 Resistance of Raphunobrassica to clubroot disease. Nature, 243:547-548

Nieuwhof, M. and D. Wiering 1963 Factors influencing the occurrence of clubroot in semi-resistant populations of Brassica oleracea L. Euphytica, 12 : 270-276

Walker, J. C. 1936 Resistance to clubroot in Brassica.Phytopathol., $26: 112$

Walker, J. C. 1939 Resistance to clubroot in varieties of turnips and rutabaga. J.Agric. Res., 59 : 815

Watson, A. 1969 Possible gene center for resistance in genus Brassica to Plasmodiophora brassicae. Econ. Bot., 23 : 245-252

Yoshikawa, H., M. Ashizawa and K. Hida 1981 Studies on the breeding of clubroot-resistance in cole crops. III. The 'insertion' screening method for clubroot-resistance. Bull. Veg. \& Omam. Crops Res. Sta., A8 : 1-21 (in Japanese with English summary)

Yoshikawa, H. 1983 Breeding for clubroot resistance of crucifer crops in Japan. JARQ., 17: 6-11

Yoshikawa, H., H. Yamagishi, S. Yuhi, U. Hanzawa and A. Yoshimura 1988 Resistance break down in the newly bred cultivars of Chinese cabbage. 1988 Abstr. Japan. Soc. Hort. Sci. Spring Meet., pp. 178-179 (in Japanese) 